\title{
An Extremely Rare Kidney Tumor: Primary Intraparenchymal Squamous Cell Carcinoma
}

\section{Oldukça Nadir Bir Böbrek Tümörü: Primer Intraparankimal Skuamöz Hücreli Karsinom}

\author{
Mustafa Yüksel1, Ali Yıldız1, Gülşah İnal2, Tümay İpekçi3, Öncel İpekçi2 \\ 1 University of Health Sciences, Antalya Training and Research Hospital, Clinic of Urology, Antalya, Turkiye \\ 2Antalya Public Hospitals Association, Clinic of Pathology, Antalya, Turkiye \\ ${ }^{3}$ Başkent University, Alanya Training and Research Hospital, Department of Urology, Antalya, Turkiye
}

\begin{abstract}
Primary squamous cell carcinoma of the renal parenchyma is a rare entity and only 4 cases have been reported in the literature. A 73-year-old female patient presented to our clinic with the complaint of right flank pain. On radiologic evaluation, a $6 \times 5 \times 4 \mathrm{~cm}$ hypodense mass showing heterogeneous contrast enhancement was observed in the upper pole of the right kidney. An uneventful laparoscopic radical nephrectomy was performed. Final pathologic diagnosis was squamous cell carcinoma. No pathological involvement was observed on postoperative positron emission tomography/computed tomography. Our patient is still alive and she has not received any adjuvant treatment.
\end{abstract}

Keywords: Squamous cell carcinoma, kidney, cancer

Öz

Primer renal parankimal renal skuamöz hücreli karsinom oldukça nadir bir patoloji olup, bugüne değin literatürde sadece 4 olgu bildirilmiştir. Yetmiş üç yaşında kadın hasta kliniğimize sağ flank ağrısı şikayetiyle başvurdu. Radyolojik incelemede sağ böbrek üst polünde $6 \times 5 \times 4$ cm boyutunda heterojen kontrastlanma gösteren hipodens kitle saptandı. Hastaya laparoskopik nefrektomi uygulandı ve patolojik incelemede tanının skuamoz hücreli karsinom olduğu görüldü. Hastaya metastaz araştırması için çekilen postoperatif pozitron emisyon tomografisi/bilgisayarlı tomografide herhangi bir patolojik tutulum görülmedi. Hastamız halen sağlıklıdır ve herhangi bir adjuvan tedavi almamıştır.

Anahtar Kelimeler: Skuamöz hücreli karsinom, böbrek, kanser

\section{Introduction}

Primary squamous cell carcinoma $(\mathrm{SCC})$ of the renal pelvis is a quite rare type of cancer accounting for $0.5-15 \%$ of all urothelial cancers. It has a poor prognosis due to its rarity and ambiguous clinical and radiological features (1). Only few cases of primary SCC of the renal pelvis have been reported in the literature $(2,3,4,5)$. In this paper, we present the case of primary SCC of the renal pelvis in a 73-year-old female patient.

\section{Case Presentation}

On March 2013, a 73-year-old female patient presented to our clinic with the complaint of right flank pain. She had no weight loss or hematuria. The patient had no history of renal calculus, urinary tract infection or pyonephrosis. On physical examination, right costovertebral angular sensitivity was noted. No palpable lymph node was observed. Routine blood examination revealed the followings: Hg: Hemoglobin 10.0 and Htc: Hematocrin 30.5. Serum urea and creatinine levels were normal. Ultrasound showed a hypoechoic mass in the upper pole of the right kidney. No hydronephrosis was observed on ultrasound. Contrast-enhanced computed tomography (CT) showed a $6 \times 5 \times 4 \mathrm{~cm}$ hypodense mass showing heterogeneous contrast enhancement in the upper pole of the right kidney (Figure 1).

Upon the suspicion of renal vein invasion, contrast enhanced

Correspondence: Mustafa Yüksel MD, University of Health Sciences, Antalya Training and Research Hospital, Clinic of Urology, Antalya, Turkiye Phone: +90 5416584098 E-mail: drmustafayuksel@outlook.com ORCID ID: orcid.org/0000-0002-2681-1245 Received: 10.11 .2016 Accepted: 17.01.2017

Cite this article as: Yüksel M, Yıldız A, İnal G, İpekçi T, İpekçi Ö. An Extremely Rare Kidney Tumor: Primary Intraparenchymal Squamous Cell Carcinoma. J Urol Surg 2017;4:208-210. 


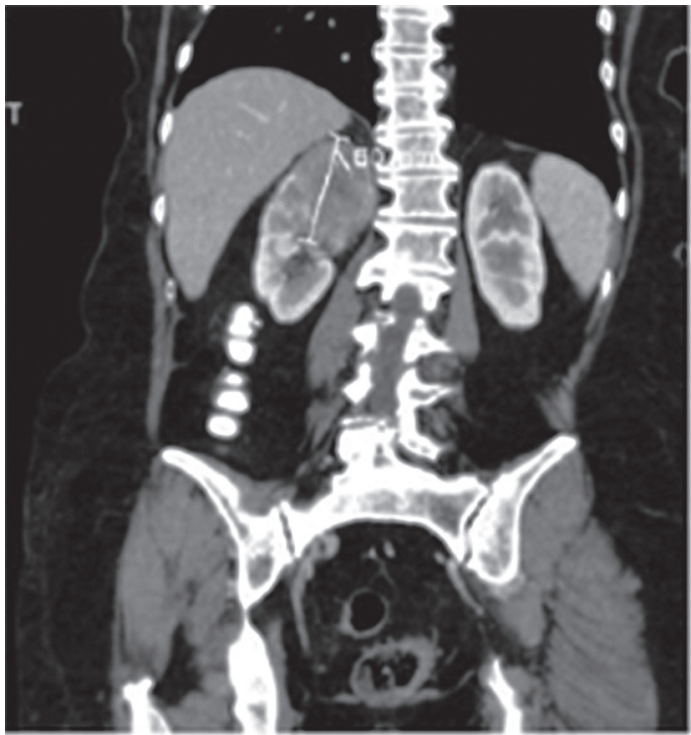

Figure 1. Computed tomography image of the tumor that is originated from the upper pole of the right kidney

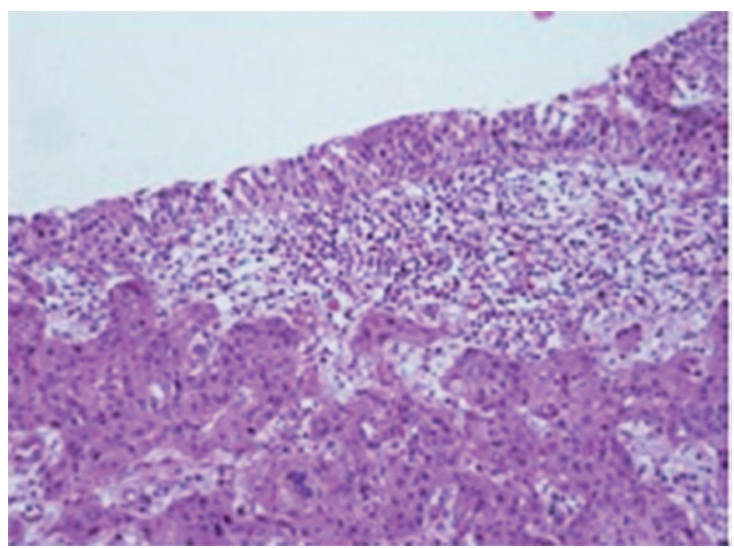

Figure 2. The relationship between the tumor and renal pelvis at $100^{x}$ magnification

abdominal magnetic resonance imaging (MRI) was performed. No vascular invasion was observed on MRI and no distant metastasis was found on preoperative abdominopelvic CT and thorax CT. An uneventful laparoscopic radical nephrectomy was performed. When the pathology specimen was analyzed, no tumor or stone was observed macroscopically in the pelvicalyceal system. The mass was located in the upper and mid pole of the kidney.

In the histopathologic examination, it was found that the tumor was moderately differentiated and contained focal necrosis; there was common infiltration in the renal parenchyma and an infiltration to the renal pelvis. Angiolymphatic invasion was present. There was no invasion in the capsule, hilus, surrenal gland, perirenal or peripelvic fatty tissue. All the surgical margins were clear (pT3Nx according to AJCC 2011 TNM staging). Although SCC invasion was histopathologically observed in the renal pelvis, no squamous metaplasia or dysplasia was found in the urothelial mucosa (Figure 2).
When all these factors were combined, it was shown that the tumor was a SCC that was primarily derived from the renal parenchyma. After the pathology was determined as SCC, positron emission tomography/CT was performed to investigate any metastasis, however, no pathological involvement was observed.

Our patient is still alive and she has not received any adjuvant treatment. The patient is under follow-up for nine months and no pathology has been detected on control imaging.

Informed consent was filled out by the patient.

\section{Discussion}

Transitional cell carcinoma (TCC) is the most common cancer of the renal pelvis. When compared to TCC, renal SCC is a rarely seen tumor mostly affecting women aged between 50 and 70 years. Primary SCC of the renal pelvis is generally diagnosed at the advanced stage and when invaded to the adjacent tissues (6). Our case was a 73-year-old female who had primary SCC of the renal parenchyma with renal pelvis invasion but no distant metastasis. Urothelial SCC generally arises through a process of metaplasia, mostly keratinizing squamous metaplasia of the urothelium. Squamous metaplasia is the precursor of SCC, however, there are disagreements in the previous studies. Such disagreements may be engendered by the rare incidence of SSC of the upper urinary system (7). The histologic features of squamos carcinoma are keratotic cellular debris, pearl formation and intercellular bridges. However, if there is a keratinized squamous metaplasia on the adjacent urothelial surface, especially if dysplasia accompanies, these findings support the diagnosis of the tumor as primary renal pelvis SCC $(8,9)$.

In our case, no squamous metaplasia/dysplasia or dysplastic urothelial component was observed in the urothelium.

Among the etiological factors; a staghorn stone that is present in the kidney for a long time, recurrent urinary tract infection, smoking, schistosomiasis, exogenous or endogenous chemicals, vitamin A deficiency, and hormonal imbalance can be specified (7). In our case, none of these predisposing factors was observed.

Since imaging properties of SCC are non specific, radiological diagnosis of SCC is not easy. The most common radiologic finding is a solid infiltrating mass with or without calcifications (10). The differential diagnosis of SCC include renal neoplasms and xanthogranulomatous pyelonephritis (XGP). Radiological feature of XGP on contrast-enhanced CT is low-attenuating areas surrounded by enhancing thinned renal parenchyma from chronic hydronephrosis (bear-paw sign) (11). However, this sign may not be seen frequently. 
When a renal tumor is diagnosed as $\mathrm{SCC}$, distinction between primary renal SCC and metastatic SCC should be done. In order to make this differentiation, the combination of clinical history, imaging and histopathological evaluation is needed (7). After metastatic SCC is excluded, differentiation between SCC of the renal pelvis and intraparenchymal SCC should also be done (10).

We did not observe paraneoplastic syndromes like hypercalcaemia, leucocytosis or thrombocytosis which could accompany SCC (12).

In the literature, there are limited number of reported cases of primary SCC of the renal parenchyma and these cases have shown poor prognosis. Our case was organ-confined and it was considered that the prognosis would be good.

\section{Ethics}

Informed Consent: Consent form was filled out by the patient.

Peer-review: Externally peer-reviewed.

\section{Authorship Contributions}

Surgical and Medical Practices: M.Y., A.Y., Concept: M.Y., A.Y., T.i., Ö.I., G.i.., Design: M.Y., A.Y., T.i., Ö.I., G.I., Data Collection or Processing: M.Y., A.Y., T.I.., Ö.I., G.I.., Analysis or Interpretation: M.Y., A.Y., T.I., Ö.I., G.I., Literature Search: M.Y., A.Y., T.I.., Ö.I., G.I.., Writing: M.Y., A.Y., T.I.., Ö.I., G.I.

Conflict of Interest: No conflict of interest was declared by the authors.

Financial Disclosure: The authors declared that this study received no financial support.

\section{References}

1. Jain A, Mittal D, Jindal A, Solanki R, Khatri S, Parikh A, Yadav K. Incidentally detected squamous cell carcinoma of renal pelvis in patients with staghorn calculi: case series with review of the literature. ISRN Oncol $2011 ; 2011: 620574$.

2. Ghosh P, Saha K. Primary intraparenchymal squamous cell carcinoma of the kidney: a rare and unique entity. Case Rep Pathol 2014;2014:256813.

3. Terada T. Synchronous squamous cell carcinoma of the kidney, squamous cell carcinoma of the ureter and sarcomatoid carcinoma of the urinary bladder: a case report. Pathol Res Pract 2010;206:379-383.

4. Kulshreshtha P, Kannan N, Bhardwaj R, Batra S. Primary squamous cell carcinoma of the renal parenchyma. Indian J Pathol Microbiol 2012;55:370371.

5. Wang Z, Yan B, Wei YB, Hu NA, Shen Q, Li D, Yang JR, Yang X. Primary kidney parenchyma squamous cell carcinoma mimicking xanthogranulomatous pyelonephritis: A case report. Oncol Lett 2016;11:2179-2181.

6. Bandyopadhyay R, Biswas S, Nag D, Ghosh AK. Squamous cell carcinoma of the renal pelvis presenting as hydronephrosis. J Cancer Res Ther 2010;6:537539.

7. Bonsib SM, Cheng L. Renal pelvis and ureter. In: Cheng L, Bostwick DG. Urologic Surgical Pathology. 2nd ed. Philadelphia, Saunders\&tElsevier, 2008, pp. 173-193.

8. Lopez-Beltran A, Montironi R, Vidal-Jimenez A, Cheng L. Pathology of tumors of the urinary bladder. In: Mikuz G. Clinical Pathology of Urologic Tumors. Florida, Informa Healthcare, 2007, pp. 57-89.

9. Maclennan GT, Cheng L. Renal pelvis and ureter. In: Maclennan GT, Cheng L. Atlas of Genitourinary Pathology. New York, Springer, 2011, pp. 123-140.

10. Bhaijee F. Squamous cell carcinoma of the renal pelvis. Ann Diagn Pathol 2012:16:124-127.

11. Dell'Aprovitola N, Guarino S, Del Vecchio W, Camera L, Chiancone F Imbimbo C, Salvatore M, Imbriaco M. Xanthogranulomatous pyelonephritis mimicking a renal cell carcinoma: a unique and challenging case. Acta Radiol Short Rep 2014;3:2047981613513763.

12. Kato N, Yasukawa K, Onozuka T, Kimura K. Paraneoplastic syndromes of leukocytosis, thrombocytosis, and hypercalcemia associated with squamous cell carcinoma. J Dermatol 1999;26:352-358. 